\title{
PENINGKATAN PENGETAHUAN DAN KETERAMPILAN TERKAIT PENCEGAHAN INFARK MIOKARDIUMDI LEMBAGA PEMASYARAKATAN PEREMPUAN KELAS IIA BANDAR LAMPUNG
}

\author{
Mentari Permatasari ${ }^{1}$, M. Arifki Zainaro ${ }^{2^{*}}$ \\ ${ }^{1}$ Lembaga Pemasyarakatan Perempuan Kelas II A Bandar Lampung \\ ${ }^{2}$ Universitas Malahayati
}

\begin{abstract}
ABSTRAK
Penyakit sistem sirkulasi (jantung atau pembuluh darah menempati posisi utama tingkat kematian yaitu sebesar 26,30\% dari jumlah total sebesar 20.800.000 orang, laporan ini berasal dari penelitian yang dilakukan oleh Badan Kesehatan Nasional. Dari total 6.000.0000 ( enam juta) orang jumlah kematian akibat jantung sebanyak 59,72\% masuk ke dalam golongan infrak miokard akut. Infark myocardium didefinisikan berupa kondisi dimana pada saat aliran darah mengalir dari pembuluh darah menuju ke arteri koroner jantung mengalami penyempitan yang akan menyebabkan matinya sel otot jantung. Tujuan kegiatan ini untuk meningkatan wawasan mengenai infark miokard akan mengalami peningkatan di lingkungan warga binaan Lembaga Pemasyarakatan Kelas II A Bandar Lampung. Metode yang digunakan penyuluhan dengan materi tentang Infark Mikoradium, publikasi/sosialisasi dan administrasi. Hasil yang didapatkan
\end{abstract}

Kata Kunci: Infark miokard, jantung, kematian

\begin{abstract}
ABSRTACT
Circulatory system diseases (heart or blood vessels) are the leading cause of death, accounting for 26.30 percent of the total population of 20,800,000 people, according to research conducted by the National Health Agency. A total of 6,000,0000 (six million) people died from heart disease, with acute myocardial infarction accounting for 59.72 percent of all deaths. Myocardial infarction is a condition in which blood flow from the blood vessels to the coronary arteries of the heart is restricted, causing heart muscle cells to die. This prevents the flow of blood around the muscle area from carrying oxygen and nutrients, preventing the heart muscle from functioning properly. A heart attack, also known as a myocardial infarction, is a medical term for a heart attack (Guyton, 2017). In the target community of Bandar Lampung's Class II A Penitentiary, activities to increase knowledge about myocardial infarction will increase.
\end{abstract}

Keywords: Myocardial infarction, heart, death 


\section{PENDAHULUAN}

Infark myocardium digambarkan sebagai disfungsinya aliran darah ke jantung yang mengakibatkan sel otot jantung manjadi mati (Magfirah, 2020; Nurramadhani, 2020). Sumbatan coroner akut terjadi apabila Aliran darah di pembuluh darah terhenti, melainkan hanya sejumlah kecil aliran kolateral dari pembuluh darah disekitarnya (Nisa, 2018; Pasaribu, 2020). Sedangkan yang menjadi daerah otot yang terdapat disekelilingnya hanya sediki atau bahkan tidak akan mendapatkan aliran darah yang menyebabkan tidak berfungsinya otot jantung, dikatakan mengalami infark (Ariani, 2012; Nabila, 2019).

IMA ( Infark Miokard Akut) adalah suatu kondisi yang menteror jiwa dengan ditandai pembentukan area nekrotik local di miokardium (Diana, 2016). Manifestasi klinis yang paling sering dirasakan oleh pasien IMA (Infark Miokard Akut) yaitu rasa nyeri dibagian dada (Kurniawati, 2018; Makanaung et al., 2019). Nyeri didefinisikan sebagai sensasi yang tidak mengenakan yang bersifat individual yang dirasakan oleh pasien tersebut. Pasien merespon nyeri yang di alami dengan cara seperti berterial, meringis dan lain-lain (Febtrina \& Febriana, 2019; Siagian \& Angeline, 2019).

Organisasi dunia yaitu WHO (World Health Organization) ditahun 2018 menyatakan bahwa 14,2 \% angka kematian di dunia disebabkan oleh infark miokard. Dan jumlah penderita penyakit jantung serta stroke akan terus mengalami kenaikan yang diperkirakan mencapai 32,4 juta kematian di tahun 2018. Hasil Riset Kesehatan Dasar Indonesia tahun 2019 yang dilakukan oleh Badan Kesehatan Nasional menunjukkan bahwa penyebab kematian utama di Indonesia adalah penyakit sistem sirkulasi (jantung atau pembuluh darah) sekitar 6.000 .000 (26,30\%) dari total keseluruhan $20.800 .000(100 \%)$. Jumlah kasus terbanyak yaitu infark miokard akut (59,72\%), penyakit jantung sistemik $(13,49 \%)$, diikuti oleh gagal jantung $(13,42 \%)$, dan penyakit jantung $(13,37 \%)$ (Riskesdas, 2019).

Berdasarkan data dari lembaga pemasyarakatan kelas iia bandar lampung tahun 2019, jumlah kasus baru penyakit infark mikoradium berjumlah 7 orang, tahun 2020 mengalami peningkatan yaitu dari 16 orang dan pada tahun 2021 jumlah kasus penyakit Infark Mikoradium (Perempuan, 2021).

\section{MASALAH}

Alasan memilih judul ini adalah berdasarkan data kesehatan Poli Klinik di Lembaga Pemasyarakatan Perempuan Kelas IIA Bandar Lampung terjadi peningkatan jumlah kasus penyakit Infark Mikoradium berjumlah 7 orang, tahun 2020 mengalami peningkatan yaitu dari 16 orang dan pada tahun 2021 jumlah kasus penyakit Infark Mikoradium. Berdasarkan data diatas terdapat peningkatan jumlah kasus penderita Infark Mikoradium, penulis tertarik melakukan kegiatan penyuluhan peningkatan pengetahuan dan keterampilan terkait pencegahan Infark Mikoradium di Lembaga Pemasyarakatan Perempuan Kelas IIA Bandar Lampung. 


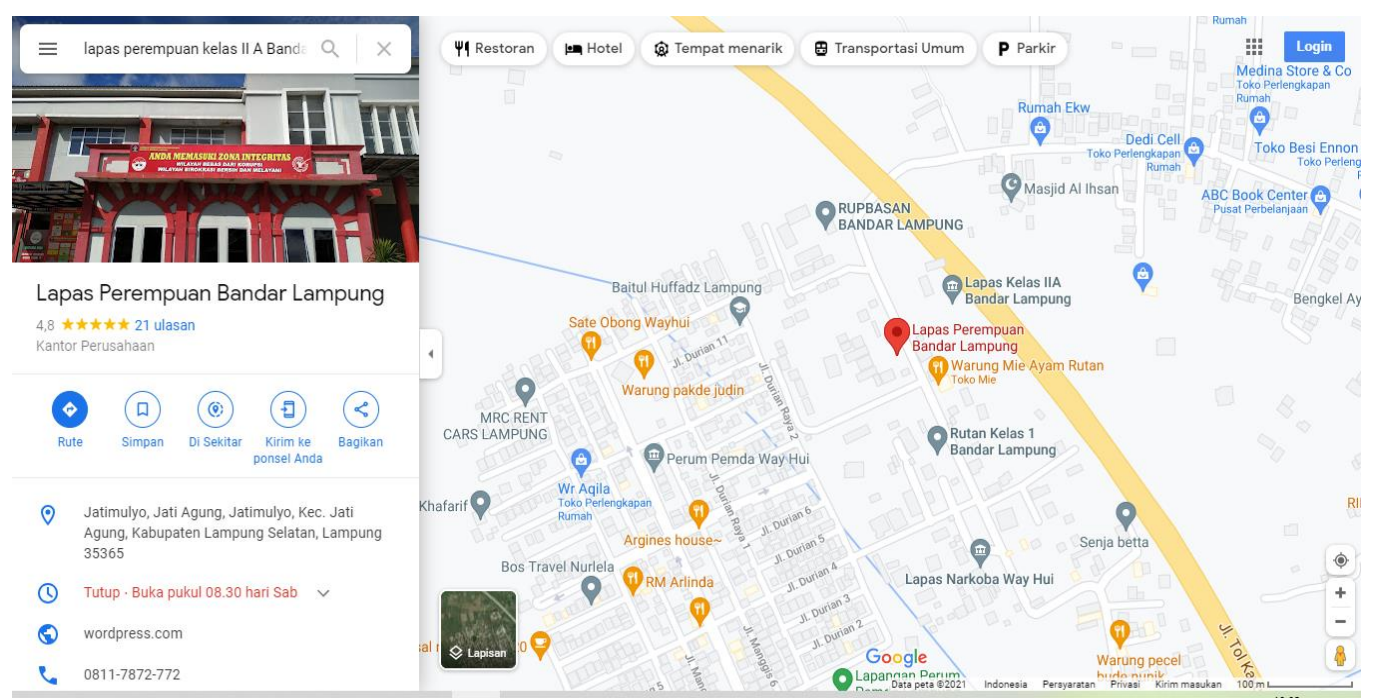

Gambar 2.1 Lokasi Lapas Perempuan Kelas II A Bandar Lampung

\section{METODE}

\section{a. Persiapan}

Persiapan penyuluhan peningkatan pengetahuan dan keterampilan terkait pencegahan Infark Mikoradium akan di Lembaga Pemasyarakatan Perempuan Kelas IIA Bandar Lampung. Peneliti menyiapkan alat dan bahan yang dibutuhkan saat penyuluhan, materi tentang Infark Mikoradium, publikasi/sosialisasi dan administrasi.

\section{b. Tahap Pelaksanaan}

Kegiatan penyuluhan peningkatan pengetahuan dan keterampilan terkait pencegahan Infark Mikoradium dilaksanakan di Lembaga Pemasyarakatan Perempuan Kelas IIA Bandar Lampung dengan peserta penyuluhan sebanyak 100 orang Warga Binaan Pemasyarakatan.

\section{c. Evaluasi}

Evaluasi bertujuan untuk melihat pengetahuan Warga Binaan Pemasyarakatan tentang definisi, penyebab, tanda dan gejala, serta cara pencegahan Infark Mikoradium sehingga program pengabdian dapat dilakukan secara maksimal.

\section{HASIL DAN PEMBAHASAN}

Kegiatan yang dilakukan berlangsung dengan baik, sebanyak $85 \%$ peserta terjadi peningkatan pengetahuan tentang pencegahan Infark Mikoradium. Hasil Penyuluh memberikan secara umum tentang peningkatan pengetahuan dan keterampilan terkait pencegahan Infark Mikoradium kepada Warga Binaan Pemasyarakatan dan terjalin kerjasama kerjasama yang baik dengan peserta penyuluhan. Peserta memberikan dukungan dan berharap ada tindak lanjut tentang materi penyuluhan yang telah diberikan. 


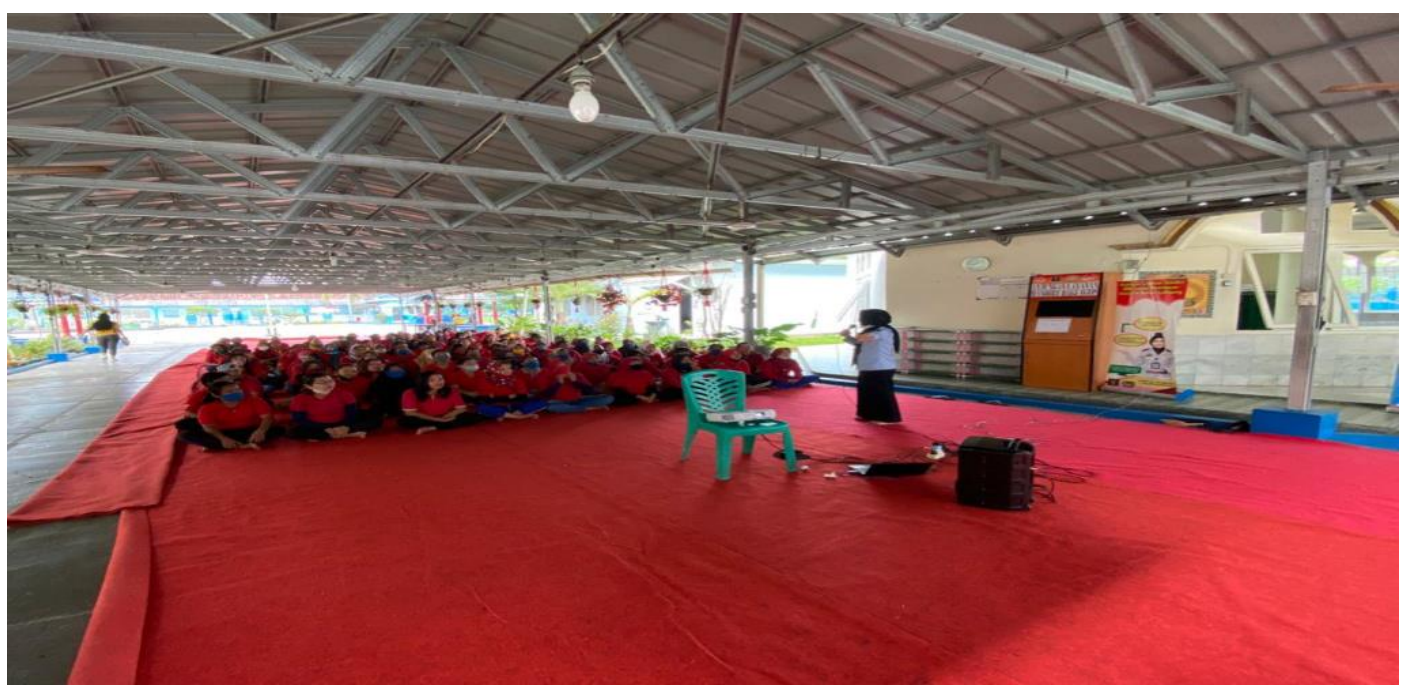

Gambar 2.2 Foto Kegiatan Penyuluhan

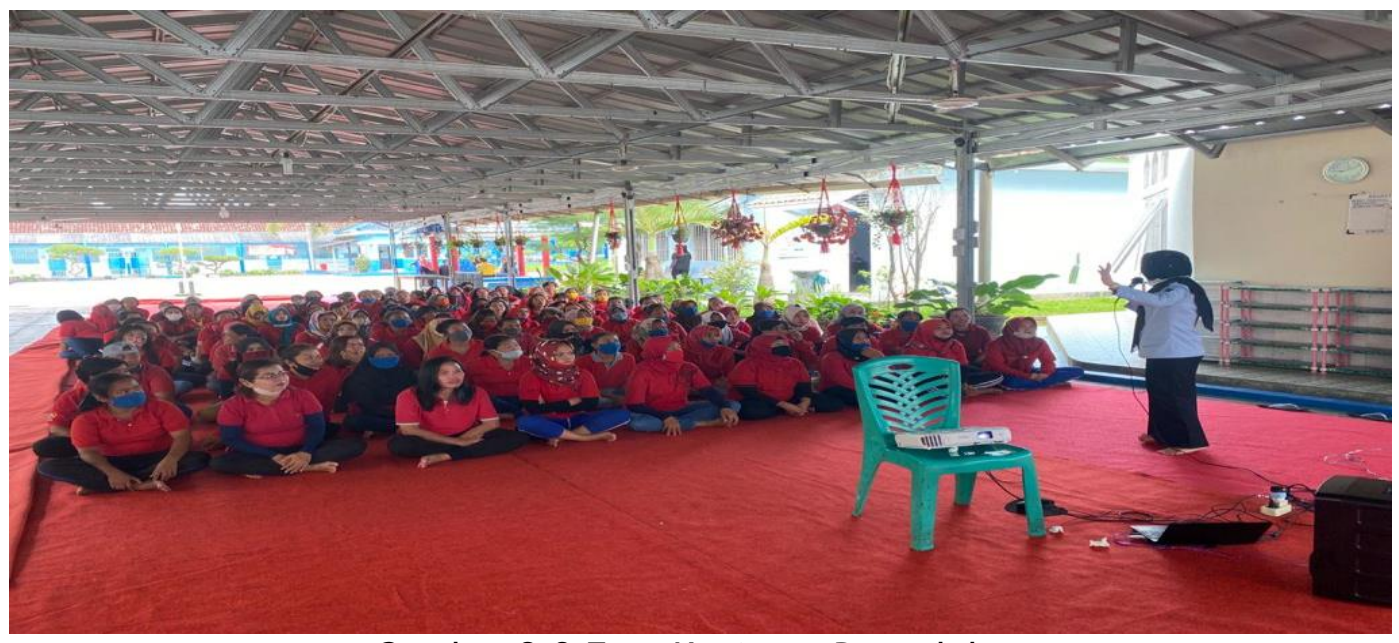

Gambar 2.3 Foto Kegiatan Penyuluhan

Berdasarkan kegiatan yang telah dilaksanakan, didapatkan beberapa hal sebagai berikut: peserta mengikuti kegiatan penyuluhan sangat aktif, hal ini terlihat dari peserta banyak yang memberikan pertanyaan dan menjawab pertanyaan yang diberikan oleh peneliti, rasa ingin tahu pasien terlihat cukup besar, ini terlihat dari keinginan peserta untuk mengadakan kegiatan penyuluhan lanjutan di masa mendatang, Terjalinnya keakraban dan suasana sesama peserta maupun dengan penyuluh.

\section{KESIMPULAN}

Terdapat peningkatan pengetahuan dan keterampilan terkait pencegahan Infark Mikoradium di Lembaga Pemasyarakatan Perempuan Kelas IIA Bandar Lampung telah berlangsung dengan baik. Jumlah peserta 100 orang terdiri dari Warga Binaan Pemasyarakatan di Lembaga Pemasyarakatan Perempuan Kelas IIA Bandar Lampung. 


\section{DAFTAR PUSTAKA}

Ariani, T. A. (2012). Sistem Neurobehaviour. In: Salemba Medika.

Diana, U. (2016). Gambaran Pemberian Auditory Murottal Terhadap Penurunan Rasa Nyeri Ibu Inpartu Kala I Fase Aktif di Rumah Bersalin Mattiro Baji Kabupaten Gowa, Sulawesi Selatan Tahun 2016 Universitas Islam Negeri Alauddin Makassar].

Febtrina, R., \& Febriana, W. (2019). Teknik Relaksasi Imajinasi Terbimbing (Guided Imagery) Menurunkan Nyeri Pasien Pasca Serangan Jantung [Guided Imagination Relaxation Techniques Reduce Patient's Pain Post Attack Heart]. Nursing Current: Jurnal Keperawatan, 5(2), 4149.

Kurniawati, T. (2018). Asuhan Keperawatan Pada Klien Infark Miokard Akut (Ima) Dengan Masalah Keperawatan Nyeri Akut" Di Ruang Icu Sentral Rsud Jombang STIKes Insan Cendekia Medika Jombang].

Magfirah, A. (2020). Studi Literature: Faktor Risiko Penyakit Jantung Koroner Terhadap Kejadian Sindrom Koroner Akut Universitas Hasanuddin].

Makanaung, C., Gobel, I., \& Welembuntu, M. (2019). The Gambaran Kebutuhan Rasa Nyaman Nyeri Pada Pasien Dengan Infark Miokard Akut Di Rsd Liun Kendage Tahuna. Jurnal Ilmiah Sesebanua, 3(2), 4351.

Nabila, H. (2019). Gangguan Fonologi Afasia Pada Penderita Stroke: Suatu Kajian Psikolinguistik. Seminar Nasional Literasi,

Nisa, A. K. (2018). Gambaran Gaya Hidup Penderita Hipertensi di Puskesmas Bonang 1 Demak Universitas Muhammadiyah Semarang].

Nurramadhani, A. A. (2020). Literatur Mengenai Penggunaan Trombolitik Pada ST-Elevation Myocardial Infarction (Stemi) Universitas Hasanuddin].

Pasaribu, E. (2020). Literatur Review Gambaran Pengetahuan Perawat Dalam Penanganan Kegawatdaruratan Pasien Penyakit Infark Miokard.

Perempuan, P. K. L. (2021). Data Dari Lembaga Pemasyarakatan Kelas IIA Bandar Lampung Tahun 2019, Jumlah Kasus Baru Penyakit Infark Mikoradium.

Riskesdas. (2019). Angka Kematian Di Dunia Disebabkan Oleh Infark Miokard.

Siagian, E., \& Angeline, D. L. (2019). In House Training Pada Perawat PK IPK IV Terhadap Pengetahuan Tentang Manajemen Nyeri. Klabat Journal of Nursing, 1(2), 19-26. 